\title{
Acrostudy: un'esperienza più che decennale dell'uso di pegvisomant nella normale pratica clinica
}

\author{
Silvia Grottoli ${ }^{1}$
}

Accettato: 14 gennaio 2022 / Pubblicato online: 21 gennaio 2022

(c) The Author(s) 2022

Commento a:

More than a decade of real-world experience of pegvisomant for acromegaly: ACROSTUDY.

M. Fleseriu, D. Führer-Sakel, A.J. van der Lely, L. De Marinis, T. Brue, J. van der Lans-Bussemaker, J. Hey-Hadavi, C. Camacho-Hubner, M.P. Wajnrajch, S. Rao Valluri, A.A. Palladino, R. Gomez, R. Salvatori. Eur J Endocrinol (2021) 185:525-538

L'acromegalia è una malattia rara caratterizzata dall'ipersecrezione patologica di GH sostenuta, nella maggior parte dei casi, da un tumore ipofisario GH secernente

Le opzioni farmacologiche di trattamento sono rappresentate dai dopamino-agonisti (bromocriptina/cabergolina), analoghi della somatostatina (lanreotide/octreotide, pasireotide) dal GH antagonista (pegvisomant).

Acrostudy è uno studio internazionale multicentrico, condotto per più un decennio (2004-2017) ed è un registro di monitoraggio post-marketing dell'efficacia e della sicurezza dell'uso prolungato di pegvisomant. Lo studio raccoglie, sostanzialmente, tutte le informazioni riguardanti l'utilizzo, nella normale pratica clinica, di pegvisomant in termini di schemi terapeutici, controllo di malattia, ormonale e morfologico, effetti collaterali e tollerabilità e andamento delle comorbilità

Dai dati ricavati da Acrostudy sono stati pubblicati molti lavori $[1,2]$ su una casistica via via sempre più numerosa $\mathrm{e}$ su molteplici argomenti relativi alla terapia dell'acromegalia con GH antagonista. Questo ha permesso di confermare l'efficacia e la sicurezza di pegvisomant, immaginare nuovi schemi e modalità di trattamento e suggerire nuove possibili indicazioni in base alle caratteristiche cliniche, co-morbilità o trattamenti pregressi.

$\triangle$ S. Grottoli

silvia.grottoli@unito.it

1 Dipartimento di Scienze Mediche, Università degli Studi di Torino, Torino, Italia
Il lavoro di Fleseriu e collaboratori riporta i risultati di efficacia e sicurezza nella popolazione globale arruolata in Acrostudy dal 2004 al 2017 (n. 2.221) in 14 stati europei e in USA

Lo studio descrive le caratteristiche demografiche e cliniche (Caucasici 92\%, M = F; età media alla diagnosi 41,1 aa e all'arruolamento 51,7 aa; durata media del trattamento 9,3 e del follow-up in Acrostudy 7,4 aa, comorbilità quali e quante, secrezione ipofisaria residua) e l'anamnesi terapeutica-farmacologica dei pazienti arruolati.

Acrostudy conferma l'ottima sicurezza del trattamento protratto con pegvisomant. Gli effetti collaterali di ogni grado considerati relati al trattamento sono stati circa il 16,5\% (i più frequenti lipoipertrofia e dolore in sede di iniezione); quelli di grado severo sono stati solo il 2,4\% (sofferenza epatica, aumento volumetrico dell'adenoma ipofisario) e solo l'1,3\% ha determinato la sospensione del farmaco. Sono state registrate 87 morti ma nessuna farmaco-relata.

L'efficacia di pegvisomant viene confermata anche nella globalità della casistica e con il protrarsi del trattamento con una media di normalizzazione di IGF-I dopo 5 anni tra 63,3 e $79,3 \%$, che rappresenta certamente un risultato tra i migliori in ambito farmacologico ma eccellente anche se paragonato ai risultati in ambito chirurgico. Si conferma, inoltre, l'effetto positivo esercitato da pegvisomant sul metabolismo glicidico sia quando somministrato da solo, sia in combinazione con gli SSA.

In conclusione, questo studio dimostra e conferma che pegvisomant ha un rapporto rischio/beneficio favorevole per i pazienti affetti da acromegalia indipendentemente dallo schema terapeutico adottato.

Open Access This article is licensed under a Creative Commons Attribution 4.0 International License, which permits use, sharing, adaptation, distribution and reproduction in any medium or format, as long as you give appropriate credit to the original author(s) and the source, provide a link to the Creative Commons licence, and indicate if changes were made. The images or other third party material in this article are included in the article's Creative Commons licence, unless indicated otherwise in a credit line to the material. If material is not included in the article's Creative Commons licence and your intended use is not 
permitted by statutory regulation or exceeds the permitted use, you will need to obtain permission directly from the copyright holder. To view a copy of this licence, visit http://creativecommons.org/licenses/by/4.0/.

\section{Bibliografia}

1. van der Lely AJ, Biller BM, Brue T et al (2012) Long-term safety of pegvisomant in patients with acromegaly: comprehensive re- view of 1288 subjects in ACROSTUDY. J Clin Endocrinol Metab 97:1589-1597

2. Buchfelder M, van der Lely AJ, Biller BM et al (2018) Long-term treatment with pegvisomant: observations from 2090 acromegaly patients in ACROSTUDY. Eur J Endocrinol 179:419-427

Nota della casa editrice Springer Nature rimane neutrale in riguardo alle rivendicazioni giurisdizionali nelle mappe pubblicate e nelle affiliazioni istituzionali. 